The new journal is produced and printed in Britain; the index, compiled by a computer, is produced in the United States.

\section{Physicists and Politics}

THE discussion of public issues by scientists is less rare in the United States than in Britain, where lips are usually sealed-in public, at least. But despite greater individual loquacity in the United States and the existence of several scientific journals which devote themselves to a discussion of public issues (Scientist and Citizen and The Bulletin of the Atomic Scientists, for example), the learned societies have so far kept their meetings and their journals free from controversial issues such as the war in Vietnam. But if Dr Charles Schwartz of the University of California at Berkeley has his way, the American Physical Society will soon change all this. He has proposed to the society an amendment which would allow discussion of any issue if one per cent of the membership of the society wished it. The suggestion was discussed at the APS meeting which has just finished in Chicago, and now goes to a full ballot of the membership of the society.

Predictably enough, the issue has roused passions on both sides. Dr Schwartz himself has had a brisk wrangle with the editors of Physics Today, an APS publication, about whether it should publish an account by him of the proposed amendment. His letter, eventually published along with others which give both sides of the issue, says that "there exists a whole range of issues where the technical activity of physicists gets tied up with political decision making". Unless physicists can make their opinions clear, Dr Schwartz says, they deserve to be judged by the dictum "silence implies consent". Dr Jay Orear, of Cornell University, who is chairman of the Federation of American Scientists, agrees. He thinks that scientists have a duty to protect the public from scientific hoaxes, large or small, and suggests that the establishment of an anti-missile defence system is a suitable place to start.

Dr Karl K. Darrow, however, the secretary emeritus of the APS, has other ideas. "The society has lived, thrived and done immeasurable service to physics under constitutions that limit its object to the advancement and diffusion of the knowledge of physics." Besides, opening the society to political discussions might endanger its tax-free status, he thinks. Edward Teller, from the Lawrence Radiation Laboratory, makes a more philosophical point. $\mathrm{He}$ says that pressure groups which exist in the United States have not been a beneficial addition to the constitution. Although, as he says, "it is a widely accepted thesis among physicists that they know best and should be consulted on every occasion", he thinks that physicists do best by keeping quiet, except on rare occasions when politicians make outrageous statements. Dr Frederick Scitz, president of the National Academy of Sciences, says that physicists have "countless avenues outside their profession through which they can express their views". He opposes the amendment, but sees no reason why Physics Today should not be used for some measure of social or political comment on subjects immediately related to physics.

In Britain, nobody has ever suggested that the Institute of Physics and the Physical Society (as it likes to call itself) should go in for political discussion, and Dr L. Cohen, secretary of the society, sounds enorm. ously relieved that this is so. "There's a difference in temperament, and, of course, we don't have the Vietnam war," he says, explaining the apparent indifference of British scientists. Nevertheless, there is occasionally a need for careful management-the CERN $300 \mathrm{GeV}$ machine, for example, is now as much a political as it is a scientific decision. Political discussions, he feels, would be a disruptive influence on the society, which already has to weather the tensions which result from a membership of both academic and indus. trial physicists.

\section{Wellcome Foundation}

For the first time the Wellcome Foundation-parent of three groups of companies: Wellcome or Burroughs Wellcome; Cooper, McDougall and Robertson Ltd.; and Calmic Ltd.-is making public its full annual report and accounts, containing a ten year record. The figures show that world-wide sales for the year ending August 31, 1967, reached a total of $£ 50.5$ million, an increase of just over 15 per cent on the previous year. And Sir Michael Perrin, chairman of the foundation, records profits before tax of $\mathfrak{f 6 . 3 9}$ million -an increase of 12.4 per cent. Furthermore, it seems that the effects of devaluation will on the whole be to the advantage of the foundation, because of its large overseas investments.

All profits received as dividends by the foundation are channelled into the support of medical rescarch. Expenditure by the group last year on research and development was $£ 2 \cdot 86$ million. One particular product of the group's commercial research during the year was the discovery of allopurinol, a drug which is used for the control of gout. A new scheme, mentioned in the annual report, will provide for all research and development within the group to be centrally controlled and co-ordinated - a scheme which, it is hoped, will extend business and increase the profitability of the group.

Research of a non-commercial nature is supported by the Wellcome Trust on a generous scale, and it has recently announced that a renewed grant of up to $\mathfrak{1} 36,000$ is being made to two British parasitologistsDr R. Lainson and Dr J. Shaw-to support their work in Belem, Brazil, on the epidemiology of cutaneous leishmaniasis. This is an insect-transferred discase causing extensive facial disfigurement.

The first grant of $£ 47,500$ was made in 1964 , and the decision to renew the grant was prompted by the encouraging results that have been obtained. Both Dr Lainson and Dr Shaw have worked on leishmaniasis in other parts of the world, but they chose Brazil for this particular programme because of the high incidence of the disease there and because of its particularly disfiguring effects--extensive destruction of the nose and parts of the throat. Together they have confirmed an carlier suspicion that the organism Leishmania is transferred to humans by a particular species of sandfly of the genus Phlebotomus from the primary host, which they have shown to be two species of forest rodents.

Although Dr Lainson believes that it is possible for an individual to develop immunity to the disease, very little is known about the details of the immunology and it has so far proved extremely difficult to detect antibodies in the blood of immune individuals. 